УДК32:39](477)«198/199»

DOI: $10.31470 / 2518-7600-2020-9 / 2-88-125$

ETHNOPOLITICAL CHALLENGES IN UKRAINE IN THE LATE 1980S IN THE 1990s: CHRONOLOGY OF EVENTS

\title{
ЕТНОПОЛІТИЧНІ ВИКЛИКИ В УКРАЇНІ НАПРИКІНЦІ 1980-Х У 1990-Х РР.: ХРОНОЛОГІЯ ПОДІЙ
}

\section{ЭТНОПОЛИТИЧЕСКИЕ ВЫЗОВЫ В УКРАИНЕ В КОНЦЕ 1980-Х В 1990-Х ГГ.: ХРОНОЛОГИЯ СОБЫТИЙ}

\section{Леся Коиур,}

кандидат історичних наук, доцент кафедри політології dombrovska_ne@ukr.net https://orcid.org/0000-00018996-1606

ДВНЗ «Переяслав-

Хмельницький

державний педагогічний

університет

імені Григорія Сковороди», вул. Сухомлинського, 30, м. Переяслав

Київська обл., Україна, 08401
Lesia Kotsur,

$\mathrm{PhD}$ in History, Senior

Lecturer, Assoc. Prof. of

Department of Political

Sciences

dombrovska_ne@ukr.net

https://orcid.org/0000-0001-

8996-1606

Pereiaslav-Khmelnytskyi

Hryhorii Skovoroda State

Pedagogical University

08401, Ukraine, Kyiv region,

Pereiaslav, Sukhomlynskyi

Str., 30

\section{ABSTRACT}

The article is devoted to the negative trends that took place in Ukrainian ethnopolitics in the late 1980's and 1990's. The proposed publication reflects in chronological order how the centers of ethnopolitical instability were formed in different regions of Ukraine (Crimea, Transcarpathia, Bukovyna, Bessarabia, south- 
eastern regions). Specifics of certain manifestations of interethnic tension are highlighted. Particular attention is paid to foreign policy factors, which had a direct impact on the formation of ethnopolitical trends, dangerous for Ukraine. In particular, there are examples of foreign policy pressure on Ukraine by the Russian Federation through persons, belonging to the Russian national minority, Russian national-cultural societies and Russian-speaking Ukrainians. It is noted that similar practices were observed in the foreign policy of Hungary and Romania, which actively spread the idea of autonomy from Ukraine with elements of separatism through the national and cultural societies of Hungarians and Romanians in some regions of Ukraine (Transcarpathia, Bukovina, Odessa). The article also allows us to trace the history of politicization of the language issue and use of this factor to incite ethnic hatred, especially in the Crimea and the south-eastern regions of Ukraine. It gives an opportunity to understand the autonomist aspirations of the so-called Ruthenian national and cultural societies of Transcarpathia, purpose of which was the political destabilization of Ukraine supported from outside; to trace the chorology of social and political activity of the Crimean Tatars and representatives of other nationalities, first of all it is a question of national and cultural societies of Greeks, Poles, Jews, Germans, Moldovans, etc. At the same time, the limited volume of the article does not allow to cover the fullness of ethnopolitical management of the 1990s regarding negative manifestations in the ethnopolitical sphere. It should be noted only that the restoration of interethnic stability in the regions of Ukraine from time to time required tough decisions by the central government. However, such decisions were seldom made, as in most cases, in places of ethnic tension, preventive explanatory talks were held to build constructive relations between national minorities and the authorities.

Keywords: national minorities, ethnopolitical management, autonomy, separatism, national-cultural societies, centers of instability. 
Постановка проблеми. Розпад СРСР призвів не лише до унезалежнення республік, а й позначився негативними проявами всередині новоутворених держав. За сприяння Кремля та інших зацікавлених держав, в Україні як і ряді інших республік, було порушено міжнаціональну рівновагу на етнічному та мовному підгрунті, що з часом призвело до надмірної політизації етнічності та етнічного регіоналізму 3 проявами відвертого сепаратизму. В реаліях українського сьогодення політизація етнічного та мовного питання $є$ не менш гострою ніж у 1990-х рр., тому актуальним видається дослідити прояви міжнаціональної напруги в Україні, які мали місце упродовж першого десятиліття української незалежності та звернути увагу на історичний досвід етнополітичного менеджменту щодо врегулювання цих явищ.

Аналіз останніх досліджень і публікацій. Окремі аспекти досліджуваної проблематики найширше висвітлені провідними фахівцями Інституту політичних i етнонаціональних досліджень імені І. Ф. Кураса НАН України (Коцур, 2017). Також до вивчення цієї проблеми долучились Ярмоленко М.I. (Ярмоленко, 2016), Кульчицький С. (Кульчицький, 2001-a), Соловей М.I. (Соловей, 2020), Барановська Н.П. (Барановська, 1994), Коцур Л.М. (Коцур, 2015), Хахула Л.І. (Хахула, 2015), Литвин В.М. (Литвин, 2003), Аппатов С., Маккан I. (Аппатов \& Маккан, 1999) та ін., які розширюють уявлення про предмет дослідження залучаючи нові джерела інформації.

Мета дослідження полягає у тому, щоб показати хронологію негативних етнополітичних викликів, які стояли перед Україною у першому десятилітті їі незалежності.

Виклад основного матеріалу. Суспільно-політичні процеси в СРСР наприкінці 1980-х рр., поряд з економічними й політичними чинниками, супроводжувались глибокою кризою міжнаціональних відносин, яка була наслідком жорсткої національної політики СРСР. Так, вже наприкінці 1980-х рр. на історичні батьківщини почали повертатись 
народи, які зазнали примусового переселення в радянські часи. До України, зокрема, почали повертатись кримські татари, греки, болгари, німці, вірмени та особи з-поміж інших національностей, які активно включились у боротьбу за свої політичні, національно-культурні та соціально-економічні права. Найбільший тиск на органи влади шляхом організації акцій протесту чинили кримські татари, які масово повертались у Крим із місць депортації (ЦК КПРС...: Арк. 22-25). Наприклад, 4 липня 1989 р. у м. Білогірську Кримської області на площі ім. В.I. Леніна 3 12:00 до 13:40 проходив мітинг кримських татар, на якому були присутні близько 300 осіб. Серед промовців було 14 осіб, з яких 7 кримських татар. Вони підіймали питання про прописку, забезпечення продовольчими талонами, працевлаштування (Секретна інформація...: Арк. 37-38). Загалом, у 1989 р. кримські татари провели 22 мітинги, в яких взяли участь 4,6 тис. осіб (Секретно...: Арк. 1-3). Паралельно польська меншина у Хмельницькій області вимагала задовольнити іiі національно-культурні потреби (школи, газети, передачі) (ЦК Компартии Украины...: Арк. 126-128).

Бурхливе повернення в Крим та у південно-східні області України великої кількості національних меншин викликало неабияке хвилювання в Москві. У результаті рішень 27 з'їзду КПРС, ХІХ Всесоюзної партійної конференції і листопадового (1988 р.) Пленуму ЦК КПРС в УРСР було активізовано процес «у галузі розвитку національного російського двомов’я, народної освіти, культури і науки» (Додаток. 3 питання.... Арк. 80) з метою посилення російської мови. Підставою для цього слугували побоювання компартійних діячів, що переселенці будуть утискати місцеве населення. Наприклад, перший секретар Кримського обкому партії Багров М.В., зазначав: «...За останні роки кількість кримських татар в області збільшилась у 4,5 раза і складає сьогодні близько 55 тис. чоловік. Потрібно прийняти відповідну державну програму, в якій необхідно відобразити, що переселенці не 
повинні ущемляти інтереси тих майже 2,5 млн чол., котрі проживають в Криму...» (Критичні зауваження...b: Арк. 8889). Також Багров М.В. зауважував, що «...у Криму як державні повинні існувати рівноправно українська і російська мови. Крим $є$ невіддільною частиною України, виривати його 3 республіки було б не розумним» (Критичні зауваження...а: Арк. 94). Хоча остання теза є дещо суперечливою, адже в іншому виступі він говорив: «...Якщо в майбутньому життя поставить питання про відродження Кримської АРСР, то ми маємо усвідомлювати, що мова йтиме про форму автономії інтернаціонально-територіальної» (Критичні зауваження...c: Арк. 82-83).

Також відзначимо, що активізація процесу у галузі так званого «національного російського двомов'я» була відповіддю на Проєкт Закону про мови в УРСР 1989 р. і не сприяла міжнаціональному діалогу. Навпаки, вдало проведена пропагандистська кампанія по дискредитації української мови центральними газетами й журналами КПРС, а також деякими друкованими органами України («Правда України», «Робітнича газета», «Прапор комунізму») (ЦК КПУ від...: Арк. 56-62) у 1989 р. призвела до того, що представники страйкових комітетів, клуби виборців ряду міст Донецької області прийняли резолюцію, в якій висловилися за статус двох державних мов, - української та російської (Критичні зауваження...d: Арк. 93).

Повернення депортованих народів й радикалізація національностей на мовному підгрунті була не єдиною проблемою 1989 року. Поряд з цим посилювались еміграційні настрої національних меншин. Зокрема, активізувалась кампанія за виїзд радянських євреїв до Ізраїлю (Довідка. Календар дат...: Арк. 228-236), які 30 травня 1989 р. провели мітинг з метою виїзду за кордон за режимними переконаннями та через заперечення родичів (Повідомлення по «ВЧ»...: Арк. 33). Подібні еміграційні настрої спостерігались й серед осіб німецької національності (Информации о работе...: 
Арк. 69-72). Набирали обертів автономістські прагнення українських угорців та греків. Свідченням цього $є$ те, що у вересні 1989 р. Берегівська районна організація Товариства угорської культури Закарпаття виступила 3 ініціативою створення на базі Берегівського району угорського автономного округу (Общество венгерской культуры....: Арк. 156; Довідка... : Арк. 157). Також висувались вимоги заборонити в місцях компактного проживання угорців поселення громадян інших національностей. Представники Товариства угорської культури Закарпаття давали обіцянки, що в разі утворення угорського адміністративного національного округу на його території за допомогою Угорської республіки буде негайно розв'язане питання 3 товарами широкого вжитку. Нав'язували ідеї національної відокремленості, виходу Закарпаття з СРСР (Про роботу з національними групами...: Арк. 43-45). Проте, автономістські прагнення греків були менш гострими ніж в угорців. Наприклад, в грудні 1989 р. жителі с. Старомлинівка Великоновосілківського району Донецької області, греки за національністю, підіймали питання про створення Старомлинівського району, який був розформований у 1959 р. (ЦК КПУ Про суспільно-політичну ситуацію...а: Арк. 235241). Водночас, як свідчать документи переважна більшість такої активності придушувалась силовими структурами.

1990 рік. Однак, ані застосування сили, ані заборони зібрань не зменшили напруги у сфері етнополітики. Навпаки, за сприяння Кремля у 1990 р. на Закарпатті почали поспішно створюватися русинські організації, 3 метою ще більшої дестабілізації краю (Заява Об'єднання...Арк. 238-241). Підсилювала цей процес політизація німецьких товариств Закарпаття та пропозиція ЦК КПУ доручити Закарпатському обкому партії вивчити громадську думку щодо можливого утворення національних районів (ЦК КПУ «Про пропозиції...: Арк. 130-133).

Поряд 3 цим, 1990 р. супроводжувався бурхливим поверненням кримських татар, болгар, вірмен, німців та ін. 
меншин на історичну батьківщину з місць депортації. 20-21 січня 1990 р. кримськими татарами проводилося пікетування (бл. 200 осіб) обкому партії (ЦК КПУ Про суспільно-політичну ситуацію...b: Арк. 51-56); Близько 100 кримських татар взяли участь в мітингах 18 і 25 лютого 1990 року, на яких висунули вимогу відставки обкому партії, облвиконкому i правоохоронних органів (Інформація про попередні висновки...: Арк.76-82). 11 травня 1990 р. під тиском кримських татар було затверджено Концепцію Державної програми по поверненню кримських татар у Кримську область, яка передбачала початок і організацію повернення з 1991 - по 1996 рр. (ЦК КПУ «Про проведену.... Арк. 112-114). Станом на 16 червня 1990 р. рух протесту у Кримській області набув масового системного характеру. Палаткові містечка протестувальників були розгорнуті під Бахчисараєм, Судаком, Алуштою, Білогорськом, с. Морське та у м. Ялті, розташований неподалік від міськвиконкому (Інформація про оперативну обстановку...: Арк. 92-94; Інформація про оперативну обстановку...c: Арк. 122). Протести у наметових містечках тривали з червня по грудень 1990 р. (Центральний державний архів...а. 196 арк.; Центральний державний архів...b: 136 арк.).

Окрім пікетувань державних установ, окремими представниками кримських татар, 3-поміж тих, хто повернулися на батьківщину, відбулося самовільне захоплення земельних ділянок. На фоні цього 15 липня 1990 р. у винрадгоспі «Судак» жителі російської національності захопили 11 га землі, розбили на 70 ділянок, встановили на них намети й вимагали закріпити їх за собою для індивідуальної забудови (Інформація про оперативну обстановку...b: Арк. 131-133).

А на фоні реалізації Закону «Про мови в Українській РСР» прийнятого наприкінці 1989 р. у 1990 році значно посилились настрої за самовизначення Криму, його автономізацію у складі УРСР, РРФСР, також розглядався статус територіальної республіки у складі СРСР, або центральне 
президентське правління. Так, на сесії (з 7 по 12 вересня 1989 року) обласні Ради прийняли заяву на адресу СРСР і РРФСР по перегляду й оцінці післявоєнних документів про статус Криму (Інформація про оперативну обстановку...d: Арк. 11-12). А вже на сесії кримської облради 26 вересня 1990 р. було прийнято рішення про створення організаційного комітету з вивчення питань, про новий статус Криму. Приводом до цього послугувало активне обговорення населенням області питань iii автономізації чи переходу до складу РРФСР для захисту від проявів так званого українського і татарського націоналізму (Інформація про оперативну обстановку...а: Арк. 106-109).

Роздмухування у ЗМІ ідеї про так званий український націоналізм, стало приводом до проведення у жовтні-листопаді 1990 р. конференції «Інтерруху Донбасу», представники якого обрали його центральну раду, прийняли статут, обговорили ситуацію в регіоні (Ярмоленко, 2016; История развития сепаратизма..., 2015). Мало того, у 1990 р. активізувались автономістські прагнення румун в Чернівецькій області. Так, на початку року ініціативна група з 10 осіб (9 румуни за національністю) провели мітинг 3 вимогою виокремити Герцаївську зону, де мешкають переважно румуни, в окремий район області. Мотивуючи це неувагою влади, до колись успішного м. Герца, що стало причиною його занепаду. Серед населення поширювалась думка «Можливо Герца знову віддати Румунії, щоб його привели до ладу». Висловлювались подібні думки й вимоги про перейменування населених пунктів (Про деякі аспекти...: Арк. 42-49).

1991 рік. Початок 1991 р. ознаменувався для України територіальними претензіями з боку Румунії. Зокрема, 24 червня 1991 р. було ухвалено декларацію Парламенту Румунії про пакт Молотова-Ріббентропа та його наслідки для України, у якій мова йшла про «приналежність Бессарабії, Герцаївського краю та Північної Буковини Румунії» (Соловей, 2020). У відповідь на це 27 липня 1991 року в м. Ізмаїлі відбулася нарада партійних і керівних органів 9 районів і міст за дністровської 
зони Одеської області. На нараді, за участі представників різних національностей було розглянуто питання «Про відношення до Декларації парламенту Румунії з приводу пакту Молотова-Ріббентропа i його наслідків для країни» $\mathrm{i}$ відповідної Декларації Народного Фронту Молдови від 24.06.1991 р. з даного питання (Комуністична партія...: Арк. 30). У ході зустрічі від імені жителів багатонаціонального краю Придунав'я вони прийняли заяву, у якій висловили своє прагнення жити 3 народами Румунії та Молдови в мирі добросусідстві та висловили протест щодо втягнення багатонаціонального регіону в зовнішньополітичні міжусобиці (Верховному Совету СССР...: Арк. 31-33).

Майже одночасно посилилась міжнаціональна напруга в Криму, пов'язана з політизацією кримськотатарського народу. 26-29 червня 1991 р. в м. Сімферополі відбувся курултай кримськотатарського народу. Курултай прийняв Декларацію про національний суверенітет кримськотатарського народу, сформував Меджліс (парламент) як «вищий, єдиний повноважений представницький орган кримськотатарського народу». Його головою обрано лідера ОКНР(Д) Мустафу Джемілєва (Арк. 25). Новостворений Меджліс уповноважений був створювати виконавчі органи влади на місцях, укладати договори й угоди. Передбачається, що він матиме власні підприємства, фонди й рахунки у банках вітчизняних та закордонних, ЗМІ та апарат штатних працівників. Це викликало неабияке занепокоєнння у тодішнього радянського керівництва, адже по суті йшлося про створення в Кримській АРСР паралельних структур влади (Про курултай...: Арк. 25-27). На додаток, у період з лютого по серпень 1991 р. до ВРУ були передані документи НРКТ, в яких подано конкретні пропозиції про представництво кримських татар у депутатському корпусі Верховної Ради СРСР, УРСР і Кримської АРСР (Запрос....: Арк. 68-69).

Не зменшувало етнополітичної напруги в Україні й звернення Товариства німців «Відергебурт» до ВРУ й АПУ від 
6 жовтня 1991 р. «Про визнання незаконними і злочинними репресивних актів проти народів, що зазнали насильницького переселення і забезпечення їх прав» (Обращение участников... : Арк. 27-28) та рішення депутатів Берегівської районної ради, велика частина 3 яких входила в громадські організації проугорського спрямування, провести референдум про створення в Берегівському районі «угорського автономного округу» (Закарпаття..., 2008: с. 586-589). Російська Федерація почала роздувати проблему кордонів, зокрема, ставити під сумнів суверенітет Криму й Одеської області (Кульчицький, 2001-b: c. 51).

1992 рік. Здобуття Україною незалежності наприкінці 1991 р. призвело до того, що негативні тенденції в етнополітичній сфері з року в рік лише посилювались й без термінового втручання органів влади могли мати непередбачувані наслідки (Коцур, 2015). Зокрема, на початку 1992 р. «...Товариство підкарпатських русинів погрозило почати загальнообласний політичний страйк, якщо парламент України та ії Президент не узаконять підкарпатських русинів як націю і не відновлять на Закарпатській області статус автономії республіки Підкарпатська Русь...» (Інформація. Про хід виконання Закону...: Арк. 169-174); сесія Берегівської районної ради ухвалила проєкт закону «Про угорський автономний територіальний округ» (Закарпаття..., 2008: с. 586589); у Криму й південно-східних областях активізувалися: РРК - Республіканський Рух Криму, осередки донського козацтва, товариства так званих новоросів (Витяг зі стенограми...: Арк. 44-46); посилились прорумунські настрої у Чернівецькій області, підтримувані інформаційним супроводом з боку деяких видань румунської преси; РФ винесла на порядок денний історичну проблему, пов'язану з передачею Україні Криму, а прийняття Конституції Криму започатковувало небезпечну для України практику зі створення паралельних державних структур в автономії (Кульчицький, 2001-b: c. 52). На додаток, 1992 р. розпочинаються перші торговельні війни 3 
РФ (м’ясна продукція) (Барановська, 1994: с. 14). Доповнювали картину соціальної та міжнаціональної напруги в Україні незначне збурення серед польської меншини, пов'язане зі спекуляціями на темі націоналізму (Хахула, 2015: с. 97-98) та систематичні мітинги кримських татар.

1993 рік. Вже на початок 1993 р. Україна опинилась у глибокій політичній та соціально-економічній кризі. На фоні цих кризових проявів на Закарпатті посилились політизація й автономістські прагнення русин, сепаратистські настрої яких вдалося придушити лише завдяки активній роботі Представника Президента в області з розв'язання проблеми (Закарпаття..., 2008: с. 581-585) та засудженню дій русин з боку Закарпатської обласної Ради. Також майже одночасно розпочалась інформаційна кампанія в угорській пресі по пропаганді ідеї «автономії Карпатського єврорегіону»; у південно-східних областях й Криму роздмухувалась проблема щодо так званої «примусової українізації» та посилились проросійські сили очолювані Ю. Мешковим в АРК (Президентові України Л.М. Кравчуку...: Арк. 117-133); не зменшувались прорумунські настрої у Чернівецькій області; Верховна Рада Російської Федерації прийняла рішення про надання Севастополю статусу міста РФ, розгорнула тиск на Україну щодо написання підручників з історії (Литвин, 2003), посилила лобіювалося питання про подвійне громадянство в Україні та підвищила ціни на нафту й газ для України 100\% до світової, започаткувавши цим енергетичну залежність України від РФ (Кульчицький, 2001-b: c. 57).

1994 рік. У цьому році негативні прояви ще більш посилились, у зв'язку з боротьбою за владу, а саме достроковими виборами президента й парламенту України. На цьому підгрунті у Криму посилюються мітинги кримських татар, пов'язані з їхніми політичними прагненнями, зокрема бажанням бути представленими у Верховній Раді України та органах влади Криму. Це значно ускладнювало ситуацію на території півострова, де розгорнула свою діяльність «Русская 
партия Крыма» й посилилась влада Ю. Мешкова (обрано президентом), яка характеризувалась сепаратистськими настроями (Довідка про міжетнічну ситуацію.... Арк. 109-114). Водночас, у процесі боротьби за владу та сприяння ззовні вкотре відбулася політизація мовного питання. Як наслідок Донецька обласна рада, вирішила винести на референдум 27 березня 1994 року питання про статус російської мови як другої державної (Президентові України Л.М. Кравчуку...: Арк. 117133), проте, своєчасна реакція з боку центру на деякий час відтермінувала цю проблему. Неспроможність РФ нав'язати Україні російську мову на державному рівні спонукала іiі виробити нову тактику тиску на Україну через так званий захист прав російськомовного населення в Україні (Президенту України Л.Д. Кучмі...Арк. 33-36). Процвітала сепаратистська діяльність прорумунських організацій у Чернівецькій області.

1995 рік характеризувався початком зведення серії монументів на честь підготовки до 1100-річчя здобуття угорцями нової батьківщини (відзначалося в 1996 році). Головною розбіжністю у цьому питанні стало будівництво пам'ятника на Верецькому перевалі. Крім цього, у регіоні фіксували випадки використання національної угорської символіки при ігноруванні українських державних символів (В мережі виклали план..., 2017). Майже одночасно у м. Сімферополі відбувся черговий мітинг кримських татар, присвячений тяжкому становищу кримськотатарського народу; посилювався проросійський сепаратизм в Криму на чолі 3 Ю. Мешковим; упродовж року порушуючи українське законодавство РФ надавала активну фінансову та гуманітарну допомогу проросійським національно-культурним товариствам (Віце-прем'єр-міністрові...: Арк. 2-4). А восени загострились стосунки з Румунією. Румунський міністр у справах молоді та спорту А. Миронов заявив, що створення Великої Румунії покладається на румунську молодь, яка живе в Україні (Аппатов \& Маккан, 1999: с. 94-95). 
1996 рік. Характерно, що після обрання нового президента України у 1994 р. етнополітична напруга почала дещо знижуватись. Новій адміністрації Л. Кучми вдалося упродовж 1995 р. погасити окремі осередки сепаратизму в Криму й південно-східних областях України (История развития сепаратизма..., 2015). Таким чином, станом на 1996 р. не вирішеною залишалася ситуація на Закарпатті, яка виникла через Форум угорських організацій Закарпаття та прагнення угорської національної меншини створити самостійний Угорський округ у складі Берегівського району (Довідка про сучасне становище угорської...: Арк. 158-160) й політизація німецької меншини, пов'язана 3 Першим з'їздом німців України, де обговорювались наміри створити паралельні органи державної влади (Аналітична довідка про.... Арк. 190195; Довідка про підготовку до.... Арк. 42-47).

1997 рік. Однак вже 1997 р. характеризувався новими культурними претензіями Угорщини щодо України. Зокрема, Будапештом була розгорнута масштабна інформаційна кампанія про необхідність зведення угорських пам'ятників в Закарпатті. Як інструменти впливу були використані дипломатичні канали, ЗМІ, громадські організації Закарпаття (В мережі виклали план...2017). Також відновились мітинги кримських татар в АРК. Мало того, Верховна Рада АР Криму прийняла Постанову № 1337-1 «Про функціонування російської мови на території Автономної Республіки Крим (постанову вдалося лише на початку 1998 р.). Після цього, низка ЗМІ АР Криму в котрий раз, поширили серію матеріалів про нібито наявну мовну дискримінацію. На цьому фоні з'явилися офіційні претензії російської сторони щодо порушення прав росіян в Україні та російськомовного населення в автономії (Претседатель...: Арк. 87-88; Депутатський запит...: Арк. 89-90), які набули ще вищого змісту після підписання Договору «Про дружбу, співробітництво і партнерство між Україною і Російською Федерацією» у травні 1997 р. (Кульчицький, 2001-а: с. 14). 
Також у 1997 р. посилилась діяльність прорумунських організацій у Чернівецькій області (Меморандум...: Арк. 215 226); з боку Румунії з'являлись антиукраїнські публікації у 3МI. Як наслідок це негативно вплинуло на відносини між двома країнами та ускладнило підписання румуно-українського політичного договору.

1998 рік. У цьому році на фоні чергових політичних перегонів активізувалися русинські організації Закарпатського краю (Довідка про соціально-економічну...: Арк. 171-182; Заява Об’єднання...: Арк. 238-241; Довідка про політичне русинство...: Арк. 96-102); деякі керівники кримськотатарського руху піддали гострій критиці дії державних органів влади України, звинувачуючи їх при цьому у пасивності щодо розв'язання нагальних соціальноекономічних та політико-правових проблем кримських татар (Державний комітет України... Од.3б. 103: Арк. 142-143); на адресу Державного комітету у справах національностей та міграції надійшов проєкт Закону України про мови в Україні від російської меншини, з метою вивести російську мову на державний рівень (Лист...: Арк. 167; Авторський колектив...: Арк. 168). Тим часом в Росії відбулося чергове засідання Ради співвітчизників при Держдумі РФ, на якому оцінка ситуації щодо задоволення прав і свобод росіян в Україні була виключно негативною. У результаті цього, упродовж 1998 р. РФ активізувала співпрацю 3 російськими національнокультурними товариствами в Україні та прийняла у першому читанні закон про захист співвітчизників за кордоном, яким передбачався «захист» усього російськомовного населення на пострадянському просторі (Федеральный Закон..., 1999).

1999 рік. Початок 1999 р. ознаменувався старими-новими викликами у сфері міжнаціональних відносин. Так, упродовж лютого-червня 1999 р. тривала підготовка й проведення 5-го Світового конгресу русин (Про проведення V...: Арк. 50-51), яка носила надмірно політизований характер й потребувала пильності з боку органів державної влади. У приміщенні 
обласного Товариства румунської культури ім. М. Емінеску відбулась ініційована старостою міської організації «Русская община» С. Воронцовим конфіденційна зустріч керівників товариств Чернівецької області 3 метою об’єднання в Конфедерацію національних товариств західних областей України у статусі політичної організації (Державний комітет України... Од.3б. 125: Арк. 50-52). Також загострилась ситуація у Придунайському регіоні Одеської області, де компактно проживають молдовани, богари та гагаузи. Там проводилася румунізація молдовського населення краю (Аналітична довідка щодо...ААк. 32-36).

Отже, результати дослідження, показують, що наприкінці 1980-х у 1990-х рр. в Україні сформувалась складна етнополітична ситуація. Вже напередодні незалежності в Україні почали формуватися основні осередки міжнаціональної напруги на етнічному підгрунті (Крим, Закарпаття, Буковина, Бессарабія, південно-східні області). Водночас, написання цієї статті з використанням хронологічного підходу мало на меті унаочнити, яку роль відіграли етнополітичні виклики в контексті політичних, духовних, культурних, соціальноекономічних трансформацій, які мали місце у суспільно-політичному житті України 1990-х рр. Також, стаття дає змогу оцінити, наскільки небезпечними можуть бути прояви політизації етнічності на шляху становлення молодої держави зі слабким соціально-економічним й політичним потенціалом.

До того ж, запропонований хронологічний огляд зроблено на основі аналітичних матеріалів Центрального державного архіву громадських об’єднань України та офіційних документів Державного комітету у справах національностей та міграції, які зберігаються у Центральному державному архіві вищих органів влади. Ці матеріали дозволяють нам простежити не лише усю палітру етнополітичної напруги, а й схарактеризувати особливості етнополітичного менеджменту 1990-х років, який характеризувався не лише рішеннями 
профілактичного змісту, а й жорсткими реакціями з боку центральної влади. Проте такі рішення приймались вкрай рідко, адже у більшості випадків в місцях міжнаціональної напруги проводилась профілактичні роз'яснювальні бесіди, спрямовані на побудову конструктивних відносин між національними меншинами й органами влади. Негативним аспектом етнополітичного менеджменту, на нашу думку, було використання центральними, регіональними й місцевими органами влади осередків національних меншин під час виборчих процесів, було присутнє спекулювання на національних й мовних почуттях. Як наслідок ці чинники не зменшували напруги у міжнаціональному середовищі, а лише сприяли політизації етнічності, радикалізували їх політичні вимоги, провокували нові негативні прецеденти в середовищі національних меншин.

\section{ДЖЕРЕЛА ТА ЛІТЕРАТУРА}

1. Авторський колектив... Авторський колектив проекту Закону України «Про мови в Україні» // Центральний державний архів вищих органів влади та управління України в м. Києві. Ф. 5252, Оп.1, Од.Зб. 112. Арк. 168.

2. Аналітична довідка про... Аналітична довідка про I-й з'їзд німців України // Центральний державний архів вищих органів влади та управління України в м. Києві. Ф. 5252, Оп.1, Од.Зб. 75. Арк. 190-195.

3. Аналітична довідка щодо... Аналітична довідка щодо недопущення порушень законодавства України з питань задоволення i розвитку національно-культурних потреб молдовської меншини в Одеській області [Управління ситуативного аналізу та інформаційного забезпечення. На виконання доручення КМУ №1534/4 від 30 січня 1999 року.] // Центральний державний архів вищих органів влади та управління України в м. Києві. Ф. 5252, Оп.1, Од.Зб. 119. Арк. 32-36. 
4. Аппатов С., Маккан I. Українсько-румунські відносини: історія та сучасність / Український історичний журнал. 1999. № 5. C. 87-100.

5. Барановська Н.П. Формування загальносоюзного продовольчого фонду та його уроки для незалежної України / Український історичний журнал, 1994. № 5. С. 3-18.

6. В мережі виклали план...(2017). В мережі виклали план створення угорської автономії на Закарпатті / Zik. 12 березня, 2017. Режим доступу: https://zik.ua/news/2017/03/12/ v_merezhi_vyklaly_plan_stvorennya_ugorskoi_avtonomii_na_zak arpatti_1058679 (Дата звернення: 22.06.2020).

7. Верховному Совету СССР... Верховному Совету СССР, Верховному Совету УССР, Верховному Совету Республики Молдова. Заявление // Центральний державний архів громадських об’єднань у м. Києві. Ф.1, Оп. 32, Спр. 2921. Арк. 31-33.

8. Витяг зі стенограми... Витяг зі стенограми у сесії Верховної Ради України «Про створення при Комісії у справах національностей експертної групи для кваліфікації проявів міжнаціональної ворожнечі та посилення правового нагляду 3 боку правових органів за діяльністю політичних і громадських організацій», 20 травня 1992 р. Осадчук П.І. // Центральний державний архів вищих органів влади та управління України в м. Києві. Ф. 5252, Оп.1, Од.3б. 10. Арк. 44-46.

9. Віце-прем'єр-міністрові... Віце-прем'єр-міністрові України І.Ф. Курасу [Лист 9-599/2, 3.11.95 від 26-27 жовтня 1995 року] // Центральний державний архів вищих органів влади та управління України в м. Києві. Ф. 5252, Оп.1, Од.3б. 52. Арк. 2-4.

10. Депутатський запит... Депутатський запит «Про дотримання вимог Закону про мови» [Народний депутат України ... лютого 1998 р. Віце-прем'єр-міністру України В.А. Смолію] // Центральний державний архів вищих органів влади та управління України в м. Києві. Ф. 5252, Оп.1, Од.Зб. 111. Арк. 89-90. 
11. Державний комітет України... (Од.Зб. 103). Державний комітет України у справах національностей та міграції [Лист від 24.02.1998, № 11-278/2 Віце-прем’єр-міністрові України В.А. Смолію] // Центральний державний архів вищих органів влади та управління України в м. Києві. Ф. 5252, Оп.1, Од.Зб. 103. Арк. 142-143.

12. Державний комітет України... (Од.Зб. 125). Державний комітет України у справах національностей та міграції [Лист від 26.02.1999 р. № 9-358/9. Керівнику Управління гуманітарної політики Адміністрації Президента України Ю.П. Богуцькому] // Центральний державний архів вищих органів влади та управління України в м. Києві. Ф. 5252, Оп.1, Од.Зб. 125. Арк. 50-52.

13. Довідка... Довідка // Центральний державний архів громадських об’єднань у м. Києві. Ф.1, Оп. 32, Спр. 2558. Арк.157.

14. Довідка. Календар дат... Довідка. Календар дат і подій на 1990 р. які можуть бути використані українськими націоналістами і сіоністами в антирадянських пропагандистських акціях // Центральний державний архів громадських об'єднань у м. Києві. Ф.1, Оп. 32, Спр. 2555. Арк. 228-236.

15. Довідка про міжетнічну ситуацію... Довідка про міжетнічну ситуацію та забезпечення Україною національнокультурних та освітніх потреб національних меншин Республіки Крим // Центральний державний архів вищих органів влади та управління України в м. Києві. Ф. 5252, Оп.1, Од.Зб. 54. Арк. 109-114.

16. Довідка про підготовку до... Довідка про підготовку до Першого з'їзду німців України та проекти документів до нього // Центральний державний архів вищих органів влади та управління України в м. Києві. Ф. 5252, Оп.1, Од.3б. 75. Арк. 42-47.

17. Довідка про політичне русинство... Довідка про політичне русинство (історичний екскурс та сучасні 
тенденції) // Центральний державний архів вищих органів влади та управління України в м. Києві. Ф. 5252, Оп.1, Од.Зб. 112. Арк. 96-102.

18. Довідка про соціально-економічну... Довідка про соціально-економічну та суспільно-політичну ситуацію в Закарпатській області. Станом на 1 липня 1998 року // Центральний державний архів вищих органів влади та управління України в м. Києві. Ф. 5252, Оп.1, Од.Зб. 106. Арк. 171-182.

19. Довідка про сучасне становище угорської... Довідка про сучасне становище угорської меншини в Україні // Центральний державний архів вищих органів влади та управління України в м. Києві. Ф. 5252, Оп.1, Од.3б. 70. Арк. 158-160.

20. Додаток. 3 питання... Додаток. 3 питання вдосконалення міжнаціональних відносин у СРСР, № 2/40 від 21 лютого 1989 р. [ЦК КПРС, Соціально-економічний відділ, товаришу Шимко B.I.] // Центральний державний архів громадських об’єднань у м. Києві. Ф. 1, Оп.32, Спр. 2643. Арк. 80.

21. Закарпаття..., (2008). Закарпаття в етнополітичному вимірі. К.: ІПіЕНД імені І.Ф.Кураса НАН України, 2008. 682с.

22. Запрос... Запрос Региональной Крымской встречи представителей национального движения крымських татар [c. Сади, с. Грушевка, Судакский p-н, 07.09.1991, 25 участников] // Центральний державний архів вищих органів влади та управління України в м. Києві. Ф. 5252, Оп.1, Од.3б. 6. Арк 68-69.

23. Заява Об’єднання... Заява Об’єднання демократичних партій і громадських організацій області Українська Народна Рада Закарпаття 3 приводу нового штабу міжнародних та внутрішніх антиукраїнських сил на Українському Закарпатті [УНР3. Українська народна рада Закарпаття № 054 від 31.05.1998 р.] // Центральний державний архів вищих органів влади та управління України в м. Києві. Ф. 5252, Оп.1, Од.Зб. 106. Арк. 238-241. 
24. Информации о работе... Информации о работе партийных организаций Херсонской области по подготовке к Пленуму ЦК КПСС и Пленуму ЦК КПУ по вопросам межнациональных отношений [Коммунистическая партия Советского Союза. Херсонский областной комитет Украины. 19.06. 1989. ЦК Компартии Украины] // Центральний державний архів громадських об'єднань у м. Києві. Ф.1, Оп. 32, Спр. 2558. Арк. 69-72.

25. История развития сепаратизма...История развития сепаратизма в Донецкой области / Никоноров Олександр. Dеро.Донбасс, 31 октября 2015. Режим доступу: https://dn.depo.ua/rus/donetsk/istoriya-rozvitku-separatizmu-vdonetskiy-oblasti-28102015090000 (22.06.2020).

26. Інформація про оперативну обстановку... Інформація про оперативну обстановку в республіці на 9 годину 16 червня 1990 року // Центральний державний архів громадських об’єднань у м. Києві. Ф.1, Оп. 32, Спр. 2874. Арк. 92-94.

27. Інформація про оперативну обстановку..... Інформація про оперативну обстановку в республіці на 9 годину 30 червня 1990 року // Центральний державний архів громадських об’єднань у м. Києві. Ф.1, Оп. 32, Спр. 2874. Арк. 106-109.

28. Інформація про оперативну обстановку...b. Інформація про оперативну обстановку в республіці на 9 годину 16 липня 1990 року // Центральний державний архів громадських об’єднань у м. Києві. Ф.1, Оп. 32, Спр. 2874. Арк. 131-133.

29. Інформація про оперативну обстановку...c. Інформація про оперативну обстановку в республіці на 9 годину 4 липня 1990 року // Центральний державний архів громадських об’єднань у м. Києві. Ф.1, Оп. 32, Спр. 2874. Арк. 122.

30. Інформація про оперативну обстановку...d. Інформація про оперативну ситуацію в республіці на 9 годину 12 вересня 1990 року // Центральний державний архів громадських об’єднань у м. Києві. Ф.1, Оп. 32, Спр. 2875. Арк. 11-12.

31. Інформація про попередні висновки... Інформація про попередні висновки виборів республіканських і місцевих Рад 
народних депутатів у Кримській області [в ЦК КПУ від 12 березня 1990 року] // Центральний державний архів громадських об’єднань у м. Києві. Ф.1, Оп. 32, Спр. 2746. Арк. 76-82.

32. Інформація. Про хід виконання Закону... Інформація. Про хід виконання Закону «Про національні меншини в Україні» в Закарпатській області // Центральний державний архів вищих органів влади та управління України в м. Києві. Ф. 5252, Оп.1, Од.3б. 53. Арк. 169-174.

33. Комуністична партія... Комуністична партія Радянського Союзу. Ізмаїльський комітет Компартії України. №152, 31 липня 1991 р. Центральный комитет Компартии Украины [Лист] // Центральний державний архів громадських об’єднань у м. Києві. Ф.1, Оп. 32, Спр. 2921. Арк. 30.

34. Коцур В.В. Вплив російського чинника на етнонаціональні процеси в Україні в 1990-х рр. / Наукові Записки ІПіЕНД ім. І.Ф. Кураса НАН України. Випуск 5-6(9192). К. : 2017. С. 368-381.

35. Коцур Л.М. Національні меншини України в етнополітичних процесах наприкінці 1980-х у 1990-х рр.: дис... кандидата іст. наук: 07.00.01 / Коцур Леся Михайлівна. Переяслав-Хмельницький, 2015. 423 с. (с. 82-99).

36. Критичні зауваження...а. Критичні зауваження i пропозиції висловлені на Пленумі ЦК КПУ 18 жовтня 1989 р., 3 питань компетенції Президії Верховної Ради УРСР // Центральний державний архів громадських об'єднань у м. Києві. Ф. 1, Оп. 32, Спр. 2649. Арк. 94.

37. Критичні зауваження...b. Критичні зауваження i пропозиції висловлені на Пленумі ЦК КПУ 18 жовтня 1989 р., 3 питань компетенції Ради Міністрів СРСР // Центральний державний архів громадських об'єднань у м. Києві. Ф. 1, Оп. 32, Спр. 2649. Арк. 88-89.

38. Критичні зауваження...c. Критичні зауваження i пропозиції висловлені на Пленумі ЦК КПУ 18 жовтня 1989 р. на адресу ЦК КПРС // Центральний державний архів 
громадських об'єднань у м. Києві. Ф. 1, Оп. 32, Спр. 2649. Арк. 82-83.

39. Критичні зауваження...d. Критичні зауваження i пропозиції висловлені на Пленумі ЦК КПУ 18 жовтня 1989 р., 3 питань компетенції Президії Верховної Ради УРСР [Тов. Вінник А.Я. - перший секретар Донецького обкому партіi] // Центральний державний архів громадських об'єднань у м. Києві. Ф. 1, Оп. 32, Спр. 2649. Арк. 93.

40. Кульчицький С., (2001-а). Кульчицький С. До 10-річчя проголошення незалежності України (Утвердження незалежної України: перше десятиліття) / Український історичний журнал. 2001, № 4. С. 3-41.

41. Кульчицький С., (2001-b). Кульчицький С. До 10-річчя проголошення незалежності України / Український історичний журнал. 2001, № 3. С. 48-68.

42. Кульчицький С., (2001-с). Кульчицький С. Утвердження незалежної України: перше десятиліття: Україна між Сходом і Заходом / Український історичний журнал. 2001, №3. С. 3-41.

43. Лист... Лист [Верховна Рада України. Комітет з питань науки і освіти № 06-6/14-869, 26 листопада 1998 року. Державний комітет у справах національностей та міграції] // Центральний державний архів вищих органів влади та управління України в м. Києві. Ф. 5252, Оп.1, Од.3б. 112. Арк. 167.

44. Литвин В.М. Самоствердження України: нелегкий поступ / Український історичний журнал. 2003, №1. С. 3-22.

45. Меморандум... Меморандум о положении румын (молдован) на Украине [Администрация Президента Украины его Превосходительству господину Президенту Леониду Кучме. Резиденция Президента Румынии его Превосходительству господину Президенту Эмилю Константинеску. Администрация Президента Республики Молдова его Превосходительству господину Президенту Петру Лучинскому] // Центральний державний архів вищих органів влади та управління України в м. Києві. Ф. 5252, Оп.1, Од. 3б. 95. Арк. 215-226. 
46. Обращение участников... Обращение участников республикансой конференции Общества немцев Украины к Верховному Совету и Кабинету Министорв Украины, 06.10.1991 р. // Центральний державний архів вищих органів влади та управління України в м. Києві. Ф. 5252, Оп.1, Од.3б. 6. Арк. 27-28.

47. Общество венгерской культуры... Общество венгерской культуры Закарпатья [Береговская районная организация, №18/89. Постановление Пленума. Ковач 3., 05.09.1989 г. Выписка из Протокола №4] // Центральний державний архів громадських об'єднань у м. Києві. Ф.1, Оп. 32, Спр. 2558. Арк. 156.

48. Повідомлення по «ВЧ»... Повідомлення по «ВЧ» Чумака А.С., 31 травня 1989 р., 9:35 // Центральний державний архів громадських об’єднань у м. Києві. Ф.1, Оп. 32, Спр. 2555. Арк. 33.

49. Президентові України Л.М. Кравчуку... Президентові України Л.М. Кравчуку [25.03.94. 10-137/1.] // Центральний державний архів вищих органів влади та управління України в м. Києві. Ф. 5252, Оп.1, Од.3б. 35. Арк. 117-133.

50. Президенту України Л.Д. Кучмі... Президенту України Л.Д. Кучмі [Лист з №11-638/1 від 24.11.95 30.11.5, 1-14/529 від 20.09.95] // Центральний державний архів вищих органів влади та управління України в м. Києві. Ф. 5252, Оп.1, Од.3б. 56. Арк. 33-36.

51. Претседатель... Претседатель Верховного Совета Автономной Республики Крым [21.04.98 р. № 28-41/267. Главе Администрации Президента Украины Кушнареву Е.П.] // Центральний державний архів вищих органів влади та управління України в м. Києві. Ф. 5252, Оп.1, Од.Зб. 111. Арк. 87-88.

52. Про деякі аспекти... Про деякі аспекти роботи 3 румунським населенням у Чернівецькій області // Центральний державний архів громадських об'єднань у м. Києві. Ф.1, Оп. 32, Спр. 2770. Арк. 42-49. 
53. Про курултай... Про курултай / з’їзд / кримськотатарського народу [ЦК Компартії України] // Центральний державний архів громадських об'єднань у м. Києві. Ф.1, Оп. 32, Спр. 2921. Арк. 25-27.

54. Про проведення V... Про проведення V Світового конгресу русинів [Лист в Державний комітет України у справах національностей та міграції від 02.03.1999, № 13-383/10. Віцепрем'єр-міністрові України В.А. Смолію] // Центральний державний архів вищих органів влади та управління України в м. Києві. Ф. 5252, Оп.1, Од.3б. 119. Арк. 50-51.

55. Про роботу з національними групами... Про роботу 3 національними групами, які проживають у Закарпатській області [Таємно. ЦК Компартії України від 21.12.1989] // Центральний державний архів громадських об'єднань у м. Києві. Ф.1, Оп. 32, Спр. 2661. Арк. 43-45.

56. Секретна інформація... Секретна інформація про ситуацію в республіці на 5 липня 1989 р. // Центральний державний архів громадських об'єднань у м. Києві. Ф.1, Оп.32, Спр. 2555. Арк. 37-40.

57. Секретно... Секретно. ЦК Компартии Украины (18.05.1989) // Центральний державний архів громадських об’єднань у м. Києві. Ф.1, Оп. 32, Спр. 2661., Арк. 1-3.

58. Соловей М.І. Українсько-румунські відносини: проблеми та перспективи їх розв'язання / Назва 3 екрана. https://vmv.kymu.edu.ua/v/03/solovey.htm (дата звернення, 17.06.2020).

59. Федеральный Закон..., (1999). Федеральный Закон Российской Федерации «О государственной политике Российской Федерации в отношении соотечественников за рубежом»: прийнятий 24 трав. 1999 року № 99-ФЗ. Режим доступу: http://sevkrimrus.narod.ru/ZAKON/sootech.htm (Дата звернення: 22.06.2020).

60. Хахула Л.І. Державотворчі та національно-демократичні процеси в Україні 1991-2014 рр.: польський суспільнополітичний дискурс / Український історичний журнал. 2015, №1. С. 92-107. 
61. Центральний державний архів...а. Центральний державний архів громадських об'єднань у м. Києві. Ф.1, Оп 32, Спр. 2874. Теж, ч.2 На 196 аркушах.

62. Центральний державний архів...b. Центральний державний архів громадських об'єднань у м. Києві. Ф.1, Оп 32 , Спр. 2875. Теж, ч.3 На 136 аркушах.

63. ЦК Компартии Украины... ЦК Компартии Украины «О некоторых аспектах работы с населением польской национальности в Хмельницкой области, решении государственно-правовых вопросов» [Комуністична партія Радянського союзу, Хмельницький обласний комітет Компартії України] // Центральний державний архів громадських об’єднань у м. Києві. Ф.1, Оп. 32, Спр. 2558. Арк. 126-128.

64. ЦК КПРС... ЦК КПРС про деякі тенденції розвитку політичної ситуації в республіці, 04. 05. 1989 р. // Центральний державний архів громадських об'єднань у м. Києві. Ф.1, Оп. №32, Спр. 2555. Арк. 22-25.

65. ЦК КПУ «Про проведену... ЦК КПУ «Про проведену Радою Міністрів УРСР роботу з вирішення питань, пов'язаних 3 організованим поверненням кримських татар в Кримську область», 23.05.1990 // Центральний державний архів громадських об'єднань у м. Києві. Ф.1, Оп. 32, Спр. 2770. Арк. 112-114.

66. ЦК КПУ «Про пропозиції... ЦК КПУ «Про пропозиції ЦК КПРС щодо вирішення проблем, які пов'язані зі становищем угорського населення у Закарпатті» // Центральний державний архів громадських об'єднань у м. Києві. Ф.1, Оп. 32, Спр. 2770. Арк. 130-133.

67. ЦК КПУ від... ЦК КПУ від 23. 02. 1990 р. // Центральний державний архів громадських об'єднань у м. Києві. Ф1, Оп. 32, Спр. 2763. Арк. 56-62.

68. ЦК КПУ Про суспільно-політичну ситуацію..... ЦК КПУ Про суспільно-політичну ситуацію в республіці від 08.12.1989 р. // Центральний державний архів громадських об’єднань у м. Києві. Ф.1, Оп. 32, Спр. 2535. Арк. 235-241. 
69. ЦК КПУ Про суспільно-політичну ситуацію...b. ЦК КПУ про суспільно-політичну ситуацію в республіці з 15 по 22 січня 1990 р. // Центральний державний архів громадських об’єднань у м. Києві. Ф.1, Оп. 32, Спр. 2873 Арк. 51-56.

70. Ярмоленко М.I. Національні меншини південної України в етнополітичних процесах кінця 80-х - початку 90-х рр. XX ст. / Науковий вісник Ізмаїльського державного гуманітарного університету. Серія «Історичні науки». 2016, Вип. 34. С. 159-167.

\section{REFERENCES}

1. Avtorskyi kolektyv... Avtorskyi kolektyv proektu Zakonu Ukrainy «Pro movy v Ukraini» // Tsentralnyi derzhavnyi arkhiv vyshchykh orhaniv vlady ta upravlinnia Ukrainy v m. Kyievi. F. 5252, Op.1, Od.Zb. 112. Ark. 168 : [in Ukrainian].

2. Analitychna dovidka pro... Analitychna dovidka pro I-i z'izd nimtsiv Ukrainy // Tsentralnyi derzhavnyi arkhiv vyshchykh orhaniv vlady ta upravlinnia Ukrainy v m. Kyievi. F. 5252, Op.1, Od.Zb. 75. Ark. 190-195: [in Ukrainian].

3. Analitychna dovidka shchodo... Analitychna dovidka shchodo nedopushchennia porushen zakonodavstva Ukrainy z pytan zadovolennia i rozvytku natsionalno-kulturnykh potreb moldovskoi menshyny v Odeskii oblasti [Upravlinnia sytuatyvnoho analizu ta informatsiinoho zabezpechennia. $\mathrm{Na}$ vykonannia doruchennia KMU №1534/4 vid 30 sichnia 1999 roku.] // Tsentralnyi derzhavnyi arkhiv vyshchykh orhaniv vlady ta upravlinnia Ukrainy $\mathrm{v} \mathrm{m}$. Kyievi. F. 5252, Op.1, Od.Zb. 119. Ark. 32-36: [in Ukrainian].

4. Appatov, S. \& Makkan I. (1999). Appatov S., Makkan I. Ukrainsko-rumunski vidnosyny: istoriia ta suchasnist [UkrainianRomanian relations: history and modernity] / Kyiv: [in Ukrainian].

5. Baranovska, N.P. (1994). Baranovska N.P. Formuvannia zahalnosoiuznoho prodovolchoho fondu ta yoho uroky dlia nezalezhnoi Ukrainy [Formation of the All-Union Food Fund and its lessons for independent Ukraine]. Kyiv: [in Ukrainian]. 
6. V merezhi vyklaly plan...(2017). V merezhi vyklaly plan stvorennia uhorskoi avtonomii na Zakarpatti / Zik. 12 bereznia, 2017. Retrieved from: https://zik.ua/news/2017/03/12/ v_merezhi_vyklaly_plan_stvorennya_ugorskoi_avtonomii_na_zak arpatti_1058679 [in Ukrainian].

7. Verkhovnomu Sovetu SSSR... Verkhovnomu Sovetu SSSR, Verkhovnomu Sovetu USSR, Verkhovnomu Sovetu Respublyky Moldova. Zaiavlenye // Tsentralnyi derzhavnyi arkhiv hromadskykh ob'iednan u m. Kyievi. F.1, Op. 32, Spr. 2921. Ark. 31-33[in Ukrainian].

8. Vytiah zi stenohramy... Vytiah zi stenohramy u sesii Verkhovnoi Rady Ukrainy «Pro stvorennia pry Komisii u spravakh natsionalnostei ekspertnoi hrupy dlia kvalifikatsii proiaviv mizhnatsionalnoi vorozhnechi ta posylennia pravovoho nahliadu $\mathrm{z}$ boku pravovykh orhaniv za diialnistiu politychnykh i hromadskykh orhanizatsii», 20 travnia 1992 r. Osadchuk P.I. // Tsentralnyi derzhavnyi arkhiv vyshchykh orhaniv vlady ta upravlinnia Ukrainy v m. Kyievi. F. 5252, Op.1, Od.Zb. 10. Ark. 44-46: [in Ukrainian].

9. Vitse-prem 'ier-ministrovi...

Vitse-prem'ier-ministrovi Ukrainy I.F. Kurasu [Lyst 9-599/2, 3.11.95 vid 26-27 zhovtnia 1995 roku] // Tsentralnyi derzhavnyi arkhiv vyshchykh orhaniv vlady ta upravlinnia Ukrainy v m. Kyievi. F. 5252, Op.1, Od.Zb. 52. Ark. 24: [in Ukrainian].

10. Deputatskyi zapyt... Deputatskyi zapyt «Pro dotrymannia vymoh Zakonu pro movy» [Narodnyi deputat Ukrainy ... liutoho 1998 r. Vitse-prem'ier-ministru Ukrainy V.A. Smoliiu] // Tsentralnyi derzhavnyi arkhiv vyshchykh orhaniv vlady ta upravlinnia Ukrainy v m. Kyievi. F. 5252, Op.1, Od.Zb. 111. Ark. 89-90: [in Ukrainian].

11. Derzhavnyi komitet Ukrainy... (Od.Zb. 103). Derzhavnyi komitet Ukrainy u spravakh natsionalnostei ta mihratsii [Lyst vid 24.02.1998, № 11-278/2 Vitse-prem’ier-ministrovi Ukrainy V.A. Smoliiu] // Tsentralnyi derzhavnyi arkhiv vyshchykh orhaniv vlady ta upravlinnia Ukrainy v m. Kyievi. F. 5252, Op.1, Od.Zb. 103. Ark. 142-143: [in Ukrainian]. 
12. Derzhavnyi komitet Ukrainy... (Od.Zb. 125). Derzhavnyi komitet Ukrainy u spravakh natsionalnostei ta mihratsii [Lyst vid 26.02.1999 r. № 9-358/9. Kerivnyku Upravlinnia humanitarnoi polityky Administratsii Prezydenta Ukrainy Yu.P. Bohutskomu] // Tsentralnyi derzhavnyi arkhiv vyshchykh orhaniv vlady ta upravlinnia Ukrainy v m. Kyievi. F. 5252, Op.1, Od.Zb. 125. Ark. 50-52: [in Ukrainian].

13. Dovidka... Dovidka // Tsentralnyi derzhavnyi arkhiv hromadskykh ob'iednan u m. Kyievi. F.1, Op. 32, Spr. 2558. Ark.157: [in Ukrainian].

14. Dovidka. Kalendar dat... Dovidka. Kalendar dat i podii na 1990 r. yaki mozhut buty vykorystani ukrainskymy natsionalistamy i sionistamy $\mathrm{v}$ antyradianskykh propahandystskykh aktsiiakh // Tsentralnyi derzhavnyi arkhiv hromadskykh ob'iednan u m. Kyievi. F.1, Op. 32, Spr. 2555. Ark. 228-236: [in Ukrainian].

15. Dovidka pro mizhetnichnu sytuatsiiu... Dovidka pro mizhetnichnu sytuatsiiu ta zabezpechennia Ukrainoiu natsionalnokulturnykh ta osvitnikh potreb natsionalnykh menshyn Respubliky Krym // Tsentralnyi derzhavnyi arkhiv vyshchykh orhaniv vlady ta upravlinnia Ukrainy v m. Kyievi. F. 5252, Op.1, Od.Zb. 54. Ark. 109-114: [in Ukrainian].

16. Dovidka pro pidhotovku do... Dovidka pro pidhotovku do Pershoho z'izdu nimtsiv Ukrainy ta proekty dokumentiv do noho // Tsentralnyi derzhavnyi arkhiv vyshchykh orhaniv vlady ta upravlinnia Ukrainy v m. Kyievi. F. 5252, Op.1, Od.Zb. 75. Ark. 42-47: [in Ukrainian].

17. Dovidka pro politychne rusynstvo... Dovidka pro politychne rusynstvo (istorychnyi ekskurs ta suchasni tendentsii) // Tsentralnyi derzhavnyi arkhiv vyshchykh orhaniv vlady ta upravlinnia Ukrainy v m. Kyievi. F. 5252, Op.1, Od.Zb. 112. Ark. 96-102: [in Ukrainian].

18. Dovidka pro sotsialno-ekonomichnu... Dovidka pro sotsialnoekonomichnu ta suspilno-politychnu sytuatsiiu v Zakarpatskii oblasti. Stanom na 1 lypnia 1998 roku // Tsentralnyi derzhavnyi arkhiv vyshchykh orhaniv vlady ta upravlinnia Ukrainy $\mathrm{v}$ m. Kyievi. F. 5252, Op.1, Od.Zb. 106. Ark. 171-182: [in Ukrainian]. 
19. Dovidka pro suchasne stanovyshche uhorskoi... Dovidka pro suchasne stanovyshche uhorskoi menshyny v Ukraini // Tsentralnyi derzhavnyi arkhiv vyshchykh orhaniv vlady ta upravlinnia Ukrainy v m. Kyievi. F. 5252, Op.1, Od.Zb. 70. Ark. 158-160: [in Ukrainian].

20. Dodatok. Z pytannia... Dodatok. Z pytannia vdoskonalennia mizhnatsionalnykh vidnosyn u SRSR, № 2/40 vid 21 liutoho 1989 r. [TsK KPRS, Sotsialno-ekonomichnyi viddil, tovaryshu Shymko V.I.] // Tsentralnyi derzhavnyi arkhiv hromadskykh ob'iednan u m. Kyievi. F. 1, Op.32, Spr. 2643. Ark. 80: [in Ukrainian].

21. Zakarpattia..., (2008). Zakarpattia v etnopolitychnomu vymiri [Transcarpathia in the ethnopolitical dimension]. Kyiv: [in Ukrainian].

22. Zapros... Zapros Rehyonalnoi Krymskoi vstrechy predstavytelei natsyonalnoho dvyzhenyia krыmskykh tatar [s. Sady, s. Hrushevka, Sudakskyi r-n, 07.09.1991, 25 uchastnykov] // Tsentralnyi derzhavnyi arkhiv vyshchykh orhaniv vlady ta upravlinnia Ukrainy v m. Kyievi. F. 5252, Op.1, Od.Zb. 6. Ark 6869: [in Russian].

23. Zaiava Ob’iednannia... Zaiava Ob'iednannia demokratychnykh partii i hromadskykh orhanizatsii oblasti Ukrainska Narodna Rada Zakarpattia z pryvodu novoho shtabu mizhnarodnykh ta vnutrishnikh antyukrainskykh syl na Ukrainskomu Zakarpatti [UNRZ. Ukrainska narodna rada Zakarpattia № 054 vid 31.05.1998 r.] // Tsentralnyi derzhavnyi arkhiv vyshchykh orhaniv vlady ta upravlinnia Ukrainy $\mathrm{v} \mathrm{m}$. Kyievi. F. 5252, Op.1, Od.Zb. 106. Ark. 238-241: [in Ukrainian].

24. Informatsyy o rabote... Ynformatsyy o rabote partyinыkh orhanyzatsyi Khersonskoi oblasty po podhotovke k Plenumu TsK KPSS y Plenumu TsK KPU po voprosam mezhnatsyonalnыkh otnoshenyi [Kommunystycheskaia partyia Sovetskoho Soiuza. Khersonskyi oblastnoi komytet Ukraynы. 19.06. 1989. TsK Kompartyy Ukraynы] // Tsentralnyi derzhavnyi arkhiv hromadskykh ob'iednan u m. Kyievi. F.1, Op. 32, Spr. 2558. Ark. 69-72: [in Russian]. 
25. Ystoryia razvytyia separatyzma ..., (2015). Ystoryia razvytyia separatyzma v Donetskoi oblasty / Nykonorov Oleksandr. Depo.Donbass, 31 oktiabria 2015. Retrieved from: https://dn.depo.ua/ rus/donetsk/ istoriya-rozvitku-separatizmu-vdonetskiy-oblasti-28102015090000 [in Russian].

26. Informatsiia pro operatyvnu obstanovku... Informatsiia pro operatyvnu obstanovku v respublitsi na 9 hodynu 16 chervnia 1990 roku // Tsentralnyi derzhavnyi arkhiv hromadskykh ob'iednan u m. Kyievi. F.1, Op. 32, Spr. 2874. Ark. 92-94: [in Ukrainian].

27. Informatsiia pro operatyvnu obstanovku ...a. Informatsiia pro operatyvnu obstanovku v respublitsi na 9 hodynu 30 chervnia 1990 roku // Tsentralnyi derzhavnyi arkhiv hromadskykh ob'iednan u m. Kyievi. F.1, Op. 32, Spr. 2874. Ark. 106-109: [in Ukrainian].

28. Informatsiia pro operatyvnu obstanovku ...b. Informatsiia pro operatyvnu obstanovku v respublitsi na 9 hodynu 16 lypnia 1990 roku // Tsentralnyi derzhavnyi arkhiv hromadskykh ob'iednan u m. Kyievi. F.1, Op. 32, Spr. 2874. Ark. 131-133: [in Ukrainian].

29. Informatsiia pro operatyvnu obstanovku ...c. Informatsiia pro operatyvnu obstanovku v respublitsi na 9 hodynu 4 lypnia 1990 roku // Tsentralnyi derzhavnyi arkhiv hromadskykh ob'iednan u m. Kyievi. F.1, Op. 32, Spr. 2874. Ark. 122: [in Ukrainian].

30. Informatsiia pro operatyvnu obstanovku...d. Informatsiia pro operatyvnu sytuatsiiu v respublitsi na 9 hodynu 12 veresnia 1990 roku // Tsentralnyi derzhavnyi arkhiv hromadskykh ob'iednan u m. Kyievi. F.1, Op. 32, Spr. 2875. Ark. 11-12: [in Ukrainian].

31. Informatsiia pro poperedni vysnovky... Informatsiia pro poperedni vysnovky vyboriv respublikanskykh i mistsevykh Rad narodnykh deputativ u Krymskii oblasti [v TsK KPU vid 12 bereznia $1990 \mathrm{roku}$ // Tsentralnyi derzhavnyi arkhiv hromadskykh ob'iednan u m. Kyievi. F.1, Op. 32, Spr. 2746. Ark. 76-82: [in Ukrainian].

32. Informatsiia. Pro khid vykonannia Zakonu... Informatsiia. Pro khid vykonannia Zakonu «Pro natsionalni menshyny v Ukraini» v Zakarpatskii oblasti // Tsentralnyi derzhavnyi arkhiv vyshchykh orhaniv vlady ta upravlinnia Ukrainy v m. Kyievi. F. 5252, Op.1, Od.Zb. 53. Ark. 169-174: [in Ukrainian]. 
33. Komunistychna partiia... Komunistychna partia Radianskoho Soiuzu. Izmailskyi komitet Kompartii Ukrainy. №152, 31 lypnia 1991 r. Tsentralnыi komytet Kompartyy Ukraynы [Lyst] // Tsentralnyi derzhavnyi arkhiv hromadskykh ob'iednan u m. Kyievi. F.1, Op. 32, Spr. 2921. Ark. 30: [in Ukrainian].

34. Kotsur, V.V., (2017). Vplyv rosiiskoho chynnyka na etnonatsionalni protsesy $\mathrm{v}$ Ukraini $\mathrm{v} 1990-\mathrm{kh}$ rr. [The influence of the Russian factor on ethno-national processes in Ukraine in the 1990s] / Kyiv: [in Ukrainian].

35. Kotsur, L.M., (2015). Natsionalni menshyny Ukrainy v etnopolitychnykh protsesakh naprykintsi 1980-kh u 1990-kh rr.: dys... kandydata ist. nauk: 07.00.01 [National minorities of Ukraine in ethnopolitical processes in the late 1980s and 1990s: candidate's dissertation. Sciences: 07.00.01] / Pereiaslav: [in Ukrainian].

36. Krytychni zauvazhennia...a. Krytychni zauvazhennia i propozytsii vyslovleni na Plenumi TsK KPU 18 zhovtnia 1989 r., z pytan kompetentsii Prezydii Verkhovnoi Rady URSR // Tsentralnyi derzhavnyi arkhiv hromadskykh ob'iednan u m. Kyievi. F. 1, Op. 32, Spr. 2649. Ark. 94: [in Ukrainian].

37. Krytychni zauvazhennia...b. Krytychni zauvazhennia i propozytsii vyslovleni na Plenumi TsK KPU 18 zhovtnia 1989 r., z pytan kompetentsii Rady Ministriv SRSR // Tsentralnyi derzhavnyi arkhiv hromadskykh ob'iednan u m. Kyievi. F. 1, Op. 32, Spr. 2649. Ark. 88-89: [in Ukrainian].

38. Krytychni zauvazhennia...c. Krytychni zauvazhennia i propozytsii vyslovleni na Plenumi TsK KPU 18 zhovtnia 1989 r. na adresu TsK KPRS // Tsentralnyi derzhavnyi arkhiv hromadskykh ob'iednan u m. Kyievi. F. 1, Op. 32, Spr. 2649. Ark. 82-83: [in Ukrainian].

39. Krytychni zauvazhennia...d. Krytychni zauvazhennia i propozytsii vyslovleni na Plenumi TsK KPU 18 zhovtnia 1989 r., z pytan kompetentsii Prezydii Verkhovnoi Rady URSR [Tov. Vinnyk A.Ya. - pershyi sekretar Donetskoho obkomu partii] // Tsentralnyi derzhavnyi arkhiv hromadskykh ob'iednan u m. Kyievi. F. 1, Op. 32, Spr. 2649. Ark. 93: [in Ukrainian]. 
40. Kulchytskyi S., (2001-a). Do 10-richchia proholoshennia nezalezhnosti Ukrainy (Utverdzhennia nezalezhnoi Ukrainy: pershe desiatylittia) [To the 10th anniversary of the proclamation of independence of Ukraine (Approval of independent Ukraine: the first decade)] / Kyiv: [in Ukrainian].

41. Kulchytskyi S., (2001-b). Do 10-richchia proholoshennia nezalezhnosti Ukrainy [To the 10th anniversary of the proclamation of independence of Ukraine] / Kyiv: [in Ukrainian].

42. Kulchytskyi S., (2001-c). Utverdzhennia nezalezhnoi Ukrainy: pershe desiatylittia: Ukraina mizh Skhodom i Zakhodom [The assertion of independent Ukraine: the first decade: Ukraine between East and West] / Kyiv: [in Ukrainian].

43. Lyst ... Lyst [Verkhovna Rada Ukrainy. Komitet z pytan nauky i osvity № 06-6/14-869, 26 lystopada 1998 roku. Derzhavnyi komitet u spravakh natsionalnostei ta mihratsii] // Tsentralnyi derzhavnyi arkhiv vyshchykh orhaniv vlady ta upravlinnia Ukrainy v m. Kyievi. F. 5252, Op.1, Od.Zb. 112. Ark. 167 : [in Ukrainian].

44. Lytvyn, V.M., (2003). Samostverdzhennia Ukrainy: nelehkyi postup [Self-affirmation of Ukraine: difficult progress] / Ukrainskyi istorychnyi zhurnal. 2003, №1. S. 3-22 : [in Ukrainian].

45. Memorandum... Memorandum o polozhenyy rumyn (moldovan) na Ukrayne [Admynystratsyia Prezydenta Ukraynы eho Prevoskhodytelstvu hospodynu Prezydentu Leonydu Kuchme. Rezydentsyia Prezydenta Rumbnyy eho Prevoskhodytelstvu hospodynu Prezydentu Эmyliu Konstantynesku. Admynystratsyia Prezydenta Respublyky Moldova eho Prevoskhodytelstvu hospodynu Prezydentu Petru Luchynskomu] // Tsentralnyi derzhavnyi arkhiv vyshchykh orhaniv vlady ta upravlinnia Ukrainy v m. Kyievi. F. 5252, Op.1, Od.Zb. 95. Ark. 215-226 : [in Russian].

46. Obrashchenye uchastnykov... Obrashchenye uchastnykov respublykansoi konferentsyy Obshchestva nemtsev Ukraynd k Verkhovnomu Sovetu y Kabynetu Mynystorv Ukraynd, 06.10.1991 r. // Tsentralnyi derzhavnyi arkhiv vyshchykh orhaniv vlady ta upravlinnia Ukrainy v m. Kyievi. F. 5252, Op.1, Od.Zb. 6. Ark. 27-28 : [in Russian]. 
47. Obshchestvo venherskoi kultury... Obshchestvo venherskoi kultury Zakarpatia [Berehovskaia raionnaia orhanyzatsyia, №18/89. Postanovlenye Plenuma. Kovach Z., 05.09.1989 h. Vыpyska yz Protokola №4] // Tsentralnyi derzhavnyi arkhiv hromadskykh ob'iednan u m. Kyievi. F.1, Op. 32, Spr. 2558. Ark.156 : [in Russian].

48. Povidomlennia po «VCh»... Povidomlennia po «VCh» Chumaka A.S., 31 travnia 1989 r., 9:35 // Tsentralnyi derzhavnyi arkhiv hromadskykh ob'iednan u m. Kyievi. F.1, Op. 32, Spr. 2555. Ark. 33 : [in Ukrainian].

49. Prezydentovi Ukrainy L.M. Kravchuku... Prezydentovi Ukrainy L.M. Kravchuku [25.03.94. 10-137/1] // Tsentralnyi derzhavnyi arkhiv vyshchykh orhaniv vlady ta upravlinnia Ukrainy v m. Kyievi. F. 5252, Op.1, Od.Zb. 35. Ark. 117-133 : [in Ukrainian].

50. Prezydentu Ukrainy L.D. Kuchmi... Prezydentu Ukrainy L.D. Kuchmi [Lyst z №11-638/1 vid 24.11.95 30.11.5, 1-14/529 vid 20.09.95] // Tsentralnyi derzhavnyi arkhiv vyshchykh orhaniv vlady ta upravlinnia Ukrainy v m. Kyievi. F. 5252, Op.1, Od.Zb. 56. Ark. 33-36 : [in Ukrainian].

51. Pretsedatel... Pretsedatel Verkhovnoho Soveta Avtonomnoi Respublyky Krym [21.04.98 r. № 28-41/267. Hlave Admynystratsyy Prezydenta Ukrayny Kushnarevu E.P.] // Tsentralnyi derzhavnyi arkhiv vyshchykh orhaniv vlady ta upravlinnia Ukrainy v m. Kyievi. F. 5252, Op.1, Od.Zb. 111. Ark. 87-88 : [in Ukrainian].

52. Pro deiaki aspekty... Pro deiaki aspekty roboty z rumunskym naselenniam u Chernivetskii oblasti // Tsentralnyi derzhavnyi arkhiv hromadskykh ob'iednan u m. Kyievi. F.1, Op. 32, Spr. 2770. Ark. 42-49 : [in Ukrainian].

53. Pro kurultai... Pro kurultai / z’izd / krymskotatarskoho narodu [TsK Kompartii Ukrainy] // Tsentralnyi derzhavnyi arkhiv hromadskykh ob'iednan u m. Kyievi. F.1, Op. 32, Spr. 2921. Ark. 25-27 : [in Ukrainian].

54. 54. Pro provedennia $V$... Pro provedennia V Svitovoho 
konhresu rusyniv [Lyst v Derzhavnyi komitet Ukrainy u spravakh natsionalnostei ta mihratsii vid 02.03.1999, № 13-383/10. Vitseprem'ier-ministrovi Ukrainy V.A. Smoliiu] // Tsentralnyi derzhavnyi arkhiv vyshchykh orhaniv vlady ta upravlinnia Ukrainy v m. Kyievi. F. 5252, Op.1, Od.Zb. 119. Ark. 50-51 : [in Ukrainian].

55. Pro robotu $z$ natsionalnymy hrupamy... Pro robotu $\mathrm{z}$ natsionalnymy hrupamy, yaki prozhyvaiut u Zakarpatskii oblasti [Taiemno. TsK Kompartii Ukrainy vid 21.12.1989] // Tsentralnyi derzhavnyi arkhiv hromadskykh ob'iednan u m. Kyievi. F.1, Op. 32, Spr. 2661. Ark. 43-45 : [in Ukrainian].

56. Sekretna informatsiia... Sekretna informatsiia pro sytuatsiiu v respublitsi na 5 lypnia 1989 r. // Tsentralnyi derzhavnyi arkhiv hromadskykh ob'iednan u m. Kyievi. F.1, Op.32, Spr. 2555. Ark. 37-40 : [in Ukrainian].

57. Sekretno... Sekretno. TsK Kompartyy Ukrayny (18.05.1989) [Secret. Central Committee of the Communist Party of Ukraine (May 18, 1989)] // Tsentralnyi derzhavnyi arkhiv hromadskykh ob'iednan u m. Kyievi. F.1, Op. 32, Spr. 2661., Ark. 1-3. : [in Ukrainian].

58. Solovei, M.I., (2020). Ukrainsko-rumunski vidnosyny: problemy ta perspektyvy yikh rozv'iazannia [Ukrainian-Romanian relations: problems and prospects for their solution] / Nazva $\mathrm{z}$ ekrana. https://vmv.kymu.edu.ua/v/03/solovey.htm: [in Ukrainian].

59. Federalnyi Zakon ..., (1999). Federalnyi Zakon Rossyiskoi Federatsyy «O hosudarstvennoi polytyke Rossyiskoi Federatsyy v otnoshenyy sootechestvennykov za rubezhom»: pryiniatyi 24 trav. 1999 roku № 99-FZ. Rezhym dostupu: http://sevkrimrus.narod.ru/ ZAKON/sootech.htm (Data zvernennia: 22.06.2020) : [in Russian].

60. Khakhula, L.I. (2015). Derzhavotvorchi ta natsionalnodemokratychni protsesy v Ukraini 1991-2014 rr.: polskyi suspilno-politychnyi dyskurs [State-building and nationaldemocratic processes in Ukraine 1991-2014: Polish socio-political discourse] / Ukrainskyi istorychnyi zhurnal. 2015, №1. S. 92-107 : [in Ukrainian]. 
61. Tsentralnyi derzhavnyi arkhiv...a. Tsentralnyi derzhavnyi arkhiv hromadskykh ob'iednan u m. Kyievi. F.1, Op 32, Spr. 2874. Tezh, ch.2 Na 196 arkushakh : [in Ukrainian].

62. Tsentralnyi derzhavnyi arkhiv...b. Tsentralnyi derzhavnyi arkhiv hromadskykh ob'iednan u m. Kyievi. F.1, Op 32, Spr. 2875. Tezh, ch.3 Na 136 arkushakh : [in Ukrainian].

63. TsK Kompartyy Ukrayny... TsK Kompartyy Ukrayny «O nekotorykh aspektakh raboty s naselenyem polskoi natsyonalnosty v Khmelnytskoi oblasty, reshenyy hosudarstvenno-pravovykh voprosov» [Komunistychna partiia Radianskoho soiuzu, Khmelnytskyi oblasnyi komitet Kompartii Ukrainy] // Tsentralnyi derzhavnyi arkhiv hromadskykh ob'iednan u m. Kyievi. F.1, Op. 32, Spr. 2558. Ark. 126-128 : [in Russian].

64. TsK KPRS... TsK KPRS pro deiaki tendentsii rozvytku politychnoi sytuatsii v respublitsi, 04. 05. 1989 r. // Tsentralnyi derzhavnyi arkhiv hromadskykh ob'iednan u m. Kyievi. F.1, Op. №32, Spr. 2555. Ark. 22-25 : [in Ukrainian].

65. TsK KPU «Pro provedenu... TsK KPU «Pro provedenu Radoiu Ministriv URSR robotu z vyrishennia pytan, pov'iazanykh $\mathrm{z}$ orhanizovanym povernenniam krymskykh tatar $\mathrm{v}$ Krymsku oblast», 23.05.1990 // Tsentralnyi derzhavnyi arkhiv hromadskykh ob'iednan u m. Kyievi. F.1, Op. 32, Spr. 2770. Ark. 112-114 : [in Ukrainian].

66. TsK KPU «Pro propozytsii... TsK KPU «Pro propozytsii TsK KPRS shchodo vyrishennia problem, yaki pov'iazani zi stanovyshchem uhorskoho naselennia u Zakarpatti»// Tsentralnyi derzhavnyi arkhiv hromadskykh ob'iednan u m. Kyievi. F.1, Op. 32, Spr. 2770. Ark. 130-133 : [in Ukrainian].

67. TsK KPU vid... TsK KPU vid 23.02. 1990 r. // Tsentralnyi derzhavnyi arkhiv hromadskykh ob'iednan u m. Kyievi. F1, Op. 32, Spr. 2763. Ark. 56-62 : [in Ukrainian].

68. TsK KPU Pro suspilno-politychnu sytuatsiiu...a. TsK KPU Pro suspilno-politychnu sytuatsiiu v respublitsi vid 08.12.1989 r. [Central Committee of the Communist Party On the socio-political situation in the republic from 08.12.1989] // Tsentralnyi derzhavnyi 
arkhiv hromadskykh ob'iednan u m. Kyievi. F.1, Op. 32, Spr. 2535. Ark. 235-241 [in Ukrainian].

69. TsK KPU Pro suspilno-politychnu sytuatsiiu...b. TsK KPU pro suspilno-politychnu sytuatsiiu v respublitsi z 15 po 22 sichnia 1990 r. // Tsentralnyi derzhavnyi arkhiv hromadskykh ob'iednan u m. Kyievi. F.1, Op. 32, Spr. 2873 Ark. 51-56 : [in Ukrainian].

70. Yarmolenko, M.I. (2016). Natsionalni menshyny pivdennoi Ukrainy v etnopolitychnykh protsesakh kintsia $80-\mathrm{kh}$ - pochatku 90-kh rr. KhKh st. [National minorities of southern Ukraine in the ethno-political processes of the late 80's - early 90's of the twentieth century] / Ismail: [in Ukrainian].

\section{АНОТАЦІЯ}

Статтю присвячено негативним тенденціям, які мали місие в українській етнополітиці наприкіниі 1980-х у 1990-х роках. У запропонованій публікаиії в хронологічному порядку зображено як формувалися осередки етнополітичної нестабільності в різних регіонах України (Крим, Закарпаття, Буковина, Бессарабія, південно-східні області). Висвітлено специфіку тих чи інших проявів міжнаціональної напруги. Особливу увагу приділено зовнішньополітичним чинникам, які мали безпосередній плив на формування небезпечних для Украӥни етнополітичних тендениій. Зокрема, наведено приклади зовнішньополітичного тиску на Україну з боку Російської Федерації через осіб, які належать до числа російської національної меншини, російські національнокультурні товариства та російськомовних украйнців. Відзначено, щз подібні практики простежувались $i$ в зовнішньополітичних діях Угорщини та Румунії, які через національно-культурні товариства угориів та румун активно поширювали в частині регіонів Украӥни (Закарпаття, Буковина, Одещина) ідеї автономізації України з елементами сепаратизму. Також стаття дозволяє простежити історію політизації мовного питання та використання цього чинника для розпалювання міжнаціональної ворожнечі, особливо у 
Криму та південно-східних областях Украӥни. Дає можливість скласти уявлення про автономістські прагнення так званих русинських національно-культурних товариств Закарпаття, метою яких була політична дестабілізація України підтримувана ззовні; простежити хорологію громадськополітичної активності кримських татар та представників інших національностей, передусім йдеться про національнокультурні товариства греків, поляків, євреїв, німиів, молдован тощуо. Водночас, обмежений обсяг статті не дозволяє висвітлити усю повноту етнополітичного менеджменту 1990-х рр. щуодо негативних проявів в етнополітичній сфері. Зазначимо лише, щзо відновлення міжнаціональної стабільності в регіонах України час від часу вимагало прийняття жорстких рішень з боку цуентральної влади. Проте такі рішення приймались вкрай рідко, адже у більшості випадків в місиях міжначіональної напруги проводилась профілактичні роз 'яснювальні бесіди, спрямовані на побудову конструктивних відносин між національними меншинами й органами влади.

Ключові слова: національні меншини, етнополітичний менеджмент, автономізація, сепаратизм, національнокультурні товариства, осередки нестабільності.

\section{АННОТАЦИЯ}

Статья посвящена негативным тенденциям, которые имели место в украинской етнополитике в конце 1980-х в 1990х годах. В предлагаемой публикации в хронологическом порядке отражено как формировались очаги этнополитической нестабильности в разных регионах Украиньл (Крыл, Закарпатье, Буковина, Бессарабия, юго-восточные области). Освещуена специифика тех или иных проявлений межнациональной напряжения. Особое внимание уделено внешнеполитическим факторам, которые оказали непосредственное влияние на формирование опасных для Украины этнополитических тенденций. B частности, приведены примеры внешнеполитического давления на Украину 
со стороны Российской Федерации через лии, которые относятся к числу русского национального меньшинства, российские национально-культурные общества и русскоязычных украинцев. Отмечено, что подобные практики прослеживались и во внешнеполитических действиях Венгрии и Румынии, которые через национально-культурные общества венгров и румын активно распространяли в части регионов Украинь (Закарпатье, Буковина, Одесская область) идеи автономизации Украины с элементами сепаратизма. Также статья позволяет проследить историю политизации языкового вопроса и использования этого фактора для разжигания межнациональной розни, особенно в Крыму и юговосточных областях Украины. Дает возможность составить представление о автономистские стремление так называемых русинских национально-культурных обществ Закарпатья, изелью которых была политическая дестабилизация Украины поддерживаемая извне; проследить хорологии общественно-политической активности крымских татар и представителей других национальностей, прежде всего речь идет о национально-культурные общества греков, поляков, евреев, немцев, молдаван и др. В то же время, ограниченный объем статьи не позволяет осветить всю полноту этнополитического менеджмента 1990-х г2. По негативных проявлениях в этнополитической сфере. Отметим лишь, что восстановление межнациональной стабильности в регионах Украины время от времени требовало принятия жестких решений со сторонь иеентральной власти. Однако такие решения принимались крайне редко, ведь в большинстве случаев в местах межнационального напряжения проводилась профилактические разъяснительные беседы, направленные на построение конструктивных отнотений между национальными меньшинствами и органами власти.

\section{Ключевые слова: нацииональные меньшинства,} этнополитический менеджмент, автономизация, сепаратизм, национально-культурные общчества, очаги нестабильности. 